\title{
Professional Risk Management in XYZ Certified Public Accountant Firm
}

\author{
${ }^{*}$ Farrah Angelica Basalama ${ }^{1}$, Agung Nugroho Soedibyo ${ }^{2}$ \\ ${ }^{1}$ Universitas Indonesia \\ ${ }^{2}$ Universitas Indonesia \\ *Corresponding author. Email: farahbasalama@gmail.com
}

\begin{abstract}
As a professional service provider, applicable ethics, standards, and regulations must be the basis for making Certified Public Accounting (CPA) Firm's procedures during the engagement. The number of financial report cases involving Public Accountants shows that there is negligence in implementing risk management at the CPA Firm. This study aimed to evaluate the application of professional risk management at CPA Firm by using Quality Control Standards 1 as the basis for assessing compliance with applicable ethics, standards, and regulations. This research was conducted using the case study method. The object of this research is XYZ CPA Firm, which is listed as the non-big four CPA Firm affiliated with the International CPA Firm. The research instruments used in this study were observation and interviews. The study results can be used as a basis for improving the implementation of risk management in XYZ CPA Firm. The study results indicate that overall, XYZ CPA Firm's risk management design has complied with applicable ethics, standards, and regulations. XYZ CPA Firm has also designed control activities for all identified risks. However, the risk management design has not been appropriately implemented. This is indicated by the internal findings related to engagement documentation. Poor implementation was caused by time constraints and a lack of coordination of the audit team. XYZ CPA Firm has also designed control activities for all identified risks. However, the risk management design has not been appropriately implemented. This is indicated by the internal findings related to engagement documentation. Poor implementation was caused by time constraints and a lack of coordination of the audit team. XYZ CPA Firm has also designed control activities for all identified risks. However, the risk management design has not been appropriately implemented. This is indicated by the internal findings related to engagement documentation. Poor implementation was caused by time constraints and a lack of coordination of the audit team.
\end{abstract}

Keywords: Hexagon Fraud, Overall Manipulation Index, Fraudulent Financial Statement.

\section{INTRODUCTION}

This research is motivated by the many cases of financial statements involving CPA Firms and Public Accountants. In evolved cases, several public accountants were also penalized for violations. Several financial statements involving CPA Firms are a case of SNP Finance, PT Garuda Indonesia, PT. Hanson International Tbk, Indosat Ooredoo Case, Baker Hughes Case, and Jiwasraya Case [1]. These cases show a risk management process that the CPA Firm has missed. In the case of SNP Finance, the public accountant was declared to have given an opinion that did not reflect the actual conditions. Meanwhile, in the case of PT Garuda Indonesia, the public accountant was declared negligent in complying with Auditing Standards (SA) 315, SA 500, and SA 560. The Financial Professional Development Center (P2PK) announced that three APs were subject to suspension sanctions in 2021. In 2019, several CPA Firms were entangled in administrative sanctions for making mistakes in auditing the Annual Financial Statements of public companies [2].

Audit quality and public trust significantly affect the CPA Firm's business continuity. Audit quality can be demonstrated by complying with applicable ethics, standards, and regulations. As a professional organization, the Indonesian Institute of Certified Public Accountants (IAPI) has ethics, standards, and 
regulations that must be complied with by all $\mathrm{CPA}$ Firms in Indonesia.

Ethics, standards, and regulations are issued to protect the public. Compliance with ethics, standards, and regulations can also assist CPA Firms in maintaining audit consistency and quality. On the other hand, if the CPA Firm gets sanctions for violating ethics, standards, and regulations, it is not impossible if the CPA F firm's reputation can be damaged so that public trust fades.

The importance of ethics, standards, and regulations show that the design of a CPA Firm's engagement procedures should be based on ethics, standards, and regulations. Compliance with ethics, standards, and regulations is a significant matter for the business continuity of a CPA Firm. Violations of ethics, standards, and regulations indicate negligence in carrying out engagement procedures. Judging from the sanctions for violations mentioned in Law Number 5 of 2011 concerning Public Accountants, the most severe sanction is the revocation of licenses. The Code of Ethics for the Professional Public Accountant (KEPAP) 2021 stated that trust in the accounting profession is why business, government, and other organizations can engage public accountants in various fields, including financial and corporate reporting assurance other professional activities. Law Number 5 of 2011 concerning Public Accountants also states that the Public Accountant is responsible for the opinion of the financial statements. This understanding is in line with the Lending Credibility Theory. Lending Credibility Theory shows that according to the public, the primary function of audit is to increase the credibility of financial statements [3].

Implementing a good risk management process should avoid negligence in carrying out engagement procedures. So that CPA Firms can minimize and avoid violations of ethics, standards, and regulations. Performing risk management does not guarantee that CPA Firms will not be violated. However, by doing risk management, CPA Firm can control all identified risks. Therefore, risk management needs to be adequately implemented by CPA Firms to maintain public trust and maintain quality.

This study aimed to find out how the procedures by CPA Firm to comply with ethics, standards, and regulations related to risk management. The involvement of the CPA Firm in the case of financial statements showed that there was the existence of a risk management process that the CPA Firm has missed. This study uses the case study method. XYZ CPA Firm was chosen as the object of research. XYZ CPA Firm is one of the non-big four CPA Firms and has international affiliations. Non-big four CPA Firm represent CPA Firm that is in average condition.
Meanwhile, the international affiliate was chosen because of the assumption that if the CPA Firm has an affiliation, the CPA Firm will apply a more detailed procedure because it has a comparison, namely with its affiliation.

There was a research gap on prior risk management research in The CPA firm. The develop a framework for risk management using a multidisciplinary approach to design risk management in CPA Firm. Their research is more focused on CPA Firms' business risks [4]. The conducts research on risk management in client acceptance. Believes that client acceptance is an essential key to reducing the risk of CPA firms facing future lawsuits [5]. This research can fill out the research gap on prior research.

\section{LITERATURE REVIEW}

\subsection{Lending Credibility Theory}

The lending credibility theory is one of the theories that emerged based on public perception. The public has a perception that the primary function of auditing is to increase the credibility of financial statements. Lending credibility theory states that audited financial statements are used by management to increase stakeholder confidence in management [3]. Have the notion that credibility is an invaluable commodity that auditors can offer to the public. If the audited financial statements lack credibility, the audited financial statements cannot be used and can be considered null and void [6].

The lending credibility theory shows that CPA Firm must have high credibility and quality in providing professional services. To achieve quality levelling IAPI, as a professional organization, issued IAPI Management Board Decree Number 4 of 2018 concerning Guidelines for Audit Quality Indicators in Public Accounting Firms. The indicators of audit quality according to the guidelines issued by IAPI are the competence of auditors; ethics and auditor independence; use of crucial engagement personnel's time; engagement quality control; the results of quality reviews or inspections of external and internal parties; engagement control span; CP A Firms organization and governance; and service fee policies. All CPA Firms are encouraged to apply these guidelines to improve audit quality and credibility.

\subsection{Quality Control Standard}

Quality Control Standard (SPM 1) is a standard published by IAPI. The SPM 1 regulates the responsibilities of the CPA Firm for the quality control system in the implementation of assurance engagements (Audits, Reviews, and Other Assurances Engagements) and non-assurance engagements. The 
elements of SPM 1 are the CPA Firms leadership's responsibility for Quality; applicable provisions of professional ethics; acceptance and continuation of certain client relationships and engagements; human Resources; execution of the engagement, monitoring, and documentation [7]. The SPM 1 must be read in conjunction with the Code of Ethics for the Professional Public Accountant (KEPAP) and the Auditing Standards, which IAPI also sets. The basic ethical principles according to KEPAP 2021 are integrity, objectivity, professional competence and due care, confidentiality, and professional behaviour [8]. All audit quality indicators on IA PI Management Board Decree Number 4 of 2018 were set on SPM 1.

\subsection{Risk Management in CPA Firm}

Risk management is a process designed by a company's board of directors, management, and other personnel, implemented in the setting of strategy throughout the company, designed to identify potential events that could affect the entity, and manage risks within its risk appetite provide assurance. Reasonable regarding the achievement of the entity's objectives [9].

Revealed that CPA Firms must have developed methods to monitor and control the risk of violations of standards and regulations or the public interest in carrying out CPA Firms' responsibilities [10]. For this reason, in researching the mechanisms used by CPA Firm to assess, monitor, and control risk, they can be divided into three groups, namely risk management before the engagement, risk management mechanisms during the engagement, and risk management mechanisms after the engagement including internal and external inspections [10].

\subsection{Prior Research}

To design risk management in CPA Firm, [4] develop a framework for risk management using a multidisciplinary approach. In their research, [4] is more focused on CPA Firms' business risks, so the risks identified are services provided by CPA Firms, clients, service users, law, and CPA Firm businesses in general [4]. [5] conducts research on risk management in client acceptance. [5] believes that client acceptance is an essential key to reducing the risk of CPA Firm will facing lawsuits in the future [5].

\subsection{Research Framework}

The research framework can be seen in Figure 1 below:

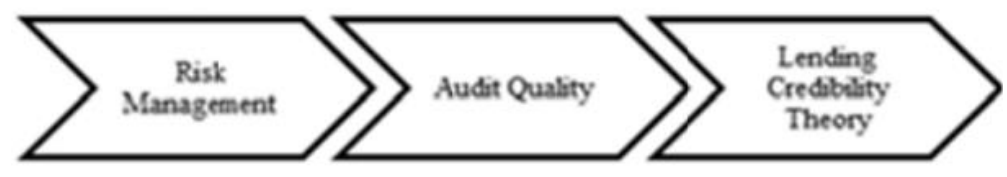

Figure 1. Conceptual Framework

\section{DATA AND METHODOLOGY}

This research uses a single case study method. XYZ CPA Firm was chosen as the object of research because it is a non-big four CPA Firm affiliated with international CPA Firms. Non-big four CPA Firms are considered to represent $\mathrm{CPA}$ firms in average condition. International affiliation is chosen as the research object because of the basic assumption that CPA Firms can implement risk management processes better. CPA firms can make comparisons and have examples for better development with the affiliation. This study will evaluate the conformity between the applicable ethics, standards, and regulations with the risk management that XYZ CPA Firm has implemented. The ethics, standards, and regulations used are SPM 1.

The instruments of this research are interviews and observations. The semi-structured type of interview was conducted with participants who are partners, managers, and team leaders who are in XYZ CPA Firm. Observations were made at XYZ CPA
Firms. Observations were made to determine the overall activities related to audit engagements in XYZ CPA Firms. This study also uses the Audit Guidelines issued by XYZ CPA Firm as a supporting document for conducting evaluations.

\section{RESULT AND DISCUSSION}

The results of this study indicate that the overall risk management design of XYZ CPA Firm has complied with SPM 1. XYZ CPA Firm's analysis results show that the policies and procedures have complied with the Elements of SPM No. 1 and the five basic principles of KEPAP 2021. The responsibility of CPA Firm leaders for quality is carried out by constantly communicating the importance of quality to employees. XY Z CPA Firm also facilitated employees to complied the CPA Firm quality control. The leadership of XYZ CPA Firm appoints the quality control division as the party that assists the leaders to maintain the quality of the XYZ CPA Firm. The five basic principles of KEPAP 2021 have also been complied with by XYZ CPA Firm through the audit 
guidelines of XYZ CPA Firm. The basic principles of KEPAP 2021 are integrity, objectivity, professional competence and due care, confidentiality, and professional behaviour. XYZ CPA Firm always strives to improve employee competence with regular training. XYZ CPA Firm also always maintains the independence of CPA Firm and auditors. Confidentiality of information has also been carried out properly with existing procedures. XYZ CPA Firm implements procedures and policies based on Auditing Standards, SPM 1, and KEPAP 2021. It showed that XYZ CPA Firm always prioritizes compliance with ethics, standards, and regulations to maintain the value and quality of the CPA Firm.

The observation results show that XYZ CPA Firm's risk management implementation is not in line with its design. An exemplary implementation must support the design to get maximum results. The internal quality controller mentioned several findings in XYZ CPA Firm. These findings indicate that there are incomplete procedures performed in the engagement. A very significant internal finding is the incompleteness of the engagement documentation. The incompleteness of a procedure can be caused by a procedure that was neglected or a procedure has been done, but the documentation is not stored correctly. Whereas XYZ CPA Firm already has a procedure for organizing and reviewing working papers before carrying out the procedure for issuing an opinion. Suppose these procedures are correctly implemented.

The researcher conducted interviews with several seniors and managers to discuss this issue. Interview results show that time is the main reason for documentation omission during the engagement. The lack of time is caused by the opinion issuance date, determined based on the client's request. Some clients requesting a specific date do not provide supporting documents on time. For example, at the beginning of the engagement, the client requests that the engagement be completed within four weeks. Thus, XYZ CPA Firm estimates that it has up to three weeks to collect all the required supporting documents. However, supporting documents can only be obtained in the fourth week at the engagement, while opinions must already be issued based on the initial agreement. Apart from the client's request, the lack of time is also caused by the lack of mature audit planning-the number of engagements that must be carried out simultaneously without careful planning results in frequent omissions.

Poor coordination between team members is also the reason for negligence in carrying out documentation procedures during the engagement. One of the responsibilities mentioned in the XYZ CPA Firm Guidelines is to oversee the progress of work, and the team leader is responsible for carrying out audit procedures. Meanwhile, the staff is responsible for assisting the team leader in carrying out audit procedures. Each team member needs good communication to carry out their respective responsibilities. An example of poor coordination in XYZ CPA Firm is the team leader does not know that the assistant does not understand a procedure, and the assistant does not know whether the procedure he is working on is right or wrong. This ignorance leads to inefficient execution of procedures.

XYZ CPA Firms realizes that the implementation of risk management has not gone according to plan. For this reason, XYZ CPA Firm is currently developing a system to facilitate the control process over engagement procedures and procedures after the engagement ends. One of the partners explained that engagement-related risks could be controlled if this system is made to make it easier for partners to monitor the progress of the audit team's work. Based on the main business of a CP A Firm, work progress is the key to risk management. Because the results of the services provided are opinions on financial statements, partners need to evaluate working papers and work progress before signing an opinion. The system under development also has several other functions, such as communication networks and document storage. Partners also feel that poor implementation is caused by company culture. Therefore, the partner seeks to improve the corporate culture by showing the leaders' commitment to maintaining the good name and improving the quality of XYZ CPA Firm.

The results of the analysis in this study are that there are four new procedures and policies, which XYZ CPA Firm can apply to make improvements in risk management in the future, as follows:

1) Disseminate audit guidelines regularly, especially during peak audit season. Although there are no updates to the guidelines, the guidelines can be redistributed as a reminder to all employees. In addition, for new employees, this manual can be used as learning material before starting the engagement.

2) Implement a reward and punishment system. Rewards and punishments are often practical and efficient strategies in risk management. With rewards and punishments, employees will be more motivated to do work. Assessment can be done based on the results of a review by the quality controller. As an initial stage, reward and punishment policies can be carried out at the manager level. Managers responsible for supervising the engagement should be able to direct the audit team to maintain audit quality. 
3) Updated the policy regarding the issuance of opinions. XYZ CPA Firm must make a firm policy for the client that an opinion can be issued at least one week after the audit team has received all supporting documents. This is done so that the audit team can complete all audit procedures without rushing.

4) Conduct risk management evaluations regularly, for example, once a year. The results of the risk management evaluation can be discussed with all employees. It is intended that risk management can be improved together. By discussing risk management between the leadership and employees, the leadership can show their sincerity and commitment in carrying out risk management to all employees. The sincerity and commitment of the leadership will undoubtedly impact the contribution of employees in implementing risk management.

This research can fill the gap with research conducted by [4], and [5]. [4] research focuses more on CPA Firm business risk management and has an approach from several disciplines, so its scope is comprehensive. While the research by [5] only considers client acceptance as the key to controlling engagement risk. So the scope of the research is very narrow. This study shows that documentation procedures are also very significant for standard and regulatory compliance in addition to client acceptance procedures. In addition to procedures, the internal environment is also very significant for the quality of the CPA Firm because, without the support of the internal environment, well-designed risk management cannot be implemented optimally.

\section{CONCLUSION}

XYZ CPA Firm designs all procedures based on applicable ethics, standards, and regulations as a professional service provider. The risk management process has resulted in several control activities that XYZ CPA Firm can implement to minimize and avoid professional risks. Some of the controls include conducting regular training, reviews by internal and international branches and affiliates, and issuing Audit Guidelines to assist employees in carrying out their responsibilities. However, the implementation of XYZ CPA Firm's risk management is still not optimal. Time and coordination are the main reasons for sub-optimal implementation.

The recommendation for further research is to analyze how CPA firms' risk management can contribute to CPA Firm revenue. This study has limited time, meaning that risk identification is only based on internal factors. This research can foster motivation for CPA Firms to improve the quality of $\mathrm{C}$ PA Firms.

\section{AUTHORS' CONTRIBUTIONS}

Farrah Angelica Basalama: Conceptualization, Methodology, Writing, Formal Analysis. Agung Nugroho Soedibyo: Supervision.

\section{ACKNOWLEDGMENTS}

Special thanks to all the members of XYZ CPA Firm for their kindness and help on my research.

\section{REFERENCES}

[1] Kampai, H. (2020). Kasus-Kasus Melilit KAP Besar di Indonesia. Akuntansi.or.id.

[2] Ayuningtyas, D., \& CNBC Indonesia. (2019). Gara-gara Lapkeu, Deretan KAP Ini Malah Kena Sanksi OJK. https://www.cnbcindonesia.com/market/20190 809 123549-17-90910/gara-gara-lapkeuderetan-kap-ini-malah-kena-sanksi-ojk.

[3] Hayes, R., Wallage, P., \& Gortemaker, H. (2015). Principal of Auditing: An Introduction to International Standards on Auditing.

[4] Folami, L. B., \& Jacobs, F. (2002). A Multidisciplinary Approach to Risk Management for Accounting Firms. Journal of Applied Business Research (JABR), 18(4), 6986. https://doi.org/10.19030/jabr.v18i4.2130.

[5] Sensi, L. (2006). Evaluasi Manajemen Risiko Kantor Akuntan Publik (KAP) dalam Keputusan Penerimaan Klien berdasarkan Pertimbangan dari Risiko Klien, Risiko Audit dan Risiko Bisnis KAP. Jurnal Akuntansi Dan Keuangan Indonesia, 3(2), 191-211.

[6] Owolabi, S. A., \& Olagunju, A. O. (2020). Historical Evolution of Audit Theory and Practice. International Journal of Management Excellence, 16(1), 2252-2259. https://doi.org/10.17722/iijme.v16i1.1197.

[7] IAPI. (2013). Standar Pengendalian Mutu No. 1.

[8] IAPI. (2021). Kode Etik Profesi Akuntan Publik 2021. Kode Etik Akuntan Publik Indonesia.

[9] COSO. (2004). Enterprise Risk ManagementIntegrated Framework. September. https://doi.org/10.1002/9781119201939.app4.

[10] Bedard, J. C., Deis, D. R., Curtis, M. B., \& Jenkins, J. G. (2008). Risk monitoring and control in audit firms: A research synthesis. Auditing: A Journal of Practice \& Theory, 27(1), 187-218. https://doi.org/10.2308/aud.2008.27.1.187. 